\title{
Study on Training Process of Green Jobs to Green Skills
}

\author{
Ping Wei ${ }^{1}$ \\ ${ }^{1}$ Vocational and Technical College of Resources and Environment, Lanzhou, Gansu, 730030 \\ 346591653@163.com
}

KEYWORDS: Training Process; Green Jobs; Green skills

\begin{abstract}
Due to global warming, environmental degradation, energy crisis and other issues serious threat to human survival and development, so that humanity had to re-examine the relationship between economic development and nature. In 1989, British economist Paul Pierce and other issued "green economy Blue Book", first proposed the concept of a green economy. Green economy raised, not only can achieve harmony between man and the environment for sustainable development, but also create a large number of green jobs, ease the employment pressure faced by countries in varying degrees. Promote green economic development is inseparable from the skills and enhance the quality of workers. Governments have given green career development and green skills training policy support and financial security, the development of green skills, talent training plan in line with the country or region, to ensure the supply of talent development of green economy.
\end{abstract}

\section{Introduction}

According to their actual situation on green jobs, various countries and regions give a different connotation. In 2008, the United Nations Environment Programme and the ILO publication "Green Jobs: towards decent work in low-carbon and sustainable world," the report, green jobs for the first time into the people's attention. The report will be defined as green jobs in agriculture, industry, services and management areas to help protect or restore the environmental quality of the work, including the delineation of the scope of energy supply (especially renewable energy supply) industry, construction, transportation, basic industries, agriculture and forestry and other six economic sectors. Green jobs are not created entirely new career, most green jobs just need to be adjusted, update and upgrade their existing knowledge and skills of employees. Development of green jobs can not only improve the natural environment, but also should be able to improve the quality of life of employees a good job. And green jobs exists in almost all areas of economic life, but in all of these areas, due to the development of green skills have not been fully appreciated, so green talent shortage has become a major factor restricting the development of green jobs.

\section{The Skills Needed for Green Jobs}

Each work will be the future green jobs, green jobs across a variety of industries, with different skill requirements and educational background requirements. Some green jobs entirely new jobs, but most are based on the traditional occupations and industries, only minor changes in the work content or capacity requirements. There is evidence that, from craftsmen, skilled workers, craftsmen and entrepreneurs to senior technicians, engineers and managers, so that all the labor of all green jobs entirely feasible, can be achieved. Green jobs have been generated, but also in many rural and 
urban sectors of the economy continue to develop. However, the skills gap has become developed and developing countries to develop a green economy constraint. Although most people are concerned about the technology, but experience has shown that the production of the weakest link in the chain will eventually be able to determine there is no qualified entrepreneurs and skilled workers, existing technology and resources can be effectively utilized, or to achieve the desired effect and economic returns. Eliminate existing skills gaps and to predict future skills needs for the achievement of a green and low carbon economy plays an important role. Only emphasized the high end of the skills and knowledge is inappropriate, strengthen the "green-collar" workers, training is also very important. Therefore, it lists the skills needed for green jobs is a vital first step, the only way to carry out specific projects to upgrade their skills. And the emerging green economy-related skills can be divided into general skills and special skills, the former green areas of work are required for each of the general, generic skills, which require different specific areas, and special skills.

Skills needed for green jobs not only in the quantity, but also in quality. The degree of change depends on the degree of green job skills change. New career, often require a higher level of qualifications, whereas in the existing career change more frequently occur in low- and middle-skill level. Each work can become environmental work, become green jobs, not all of the new skills needed for green jobs is technical. Skills also need to involve the relevant regulatory knowledge and ability to maintain skills, innovation management, and leadership skills. Obviously, some sectors more than other sectors career change, but all departments are generally required its staff in certain environments, such as in energy and resource efficiency of skills, ability level, in line with environmental legislation and to reduce environmental pollution and waste, which is green generic skill needed for the work. For example, there is a good scientific knowledge, management, leadership, communication skills, can improve the efficiency of resource use and improving green workplace, understand the environmental legislation. Sound scientific knowledge, including engineering, environmental and biological aspects, is a general feature of many emerging green economy needs skills. A recent ILO survey showed that the skills needed for sustainable development, and in a wide range of generic skills. Are there common skills available capacity and intellectual qualities, will be important factors determine success and failure. Generic skills, if good leadership, communication, teamwork, project management, understanding of sustainable development, effective financial management and understand the local economic development of the democratic process, these skills need, in varying degrees and at different levels to play the role of sustainable social and economic development. In the survey, about one hundred years in different occupations, all of which require their expertise, but they also need the above-mentioned generic skills, so that they can work together to provide services for the region.

\section{Vocational Education Skills Training under Green Jobs Concept}

Each work will be the future green jobs, to varying degrees, to continuously improve the efficiency of resource use. Learn green work employment environment, solve the shortage of green jobs skills, the need to support vocational education and training system. The Green Revolution has become a global concern, the world in action. Such as the United States, we have launched a "green employment and training programs." In China, there are more and more industries and sectors began to pay attention to the use of green technologies, such as green, recycling and processing waste materials, wind energy, promote green hotel standards, and so on, but we noticed that in all of these field, green talent is becoming the bottleneck of green technology applications. Green thinking and green skills in the existing education and other socio-economic policies have failed to 
get enough attention. Therefore, we must strengthen training for green jobs required vocational skills.

Green Skills Training green jobs and a green economy is an indispensable factor. ILO skills and employability and green jobs program and the European Centre for the Development of Vocational Training Cooperation green economy skills required for global research project conducted in 21 countries. The results of a comprehensive study report shows that skills development is crucial to the employment potential of green growth, but the shortage of skilled personnel is becoming an obstacle to the realization of this potential. Green talent plays an important role in sustainable development of society, all the green concept, green skills, green only by the action of talent in order to better serve the coordinated development of the socio-economic and ecological environment. In the people's pursuit of "white collar", "gold collar" Today, vocational education skills training should correct orientation of training objectives for the community to enter more "green collar" talent, cultivate green security personnel. As defined by United Nations Environment Programme, the "green-collar" class refers engaged in agriculture, manufacturing, research and development, management and service activities of the workers, their work can play an important role in the maintenance and restoration of environmental quality, such as help to protect ecosystems and biodiversity, helps improve efficiency by reducing the consumption of energy and other resources, as well as help to reduce waste and pollutant emissions. Today, the demand community "green collar" is increasing, businesses are actively engaged in energy-saving, low-carbon, environmental protection and other related work, talent training goal green undoubtedly be able to fill the role of a huge talent gap, more Good to achieve comprehensive and sustainable development of society.

Has an important link between education and training and the economy, how to work efficiently, spread green technologies, it is an important task of human resource development and vocational education and training. Rapid technological innovation and market reaction need trained professionals to spread. In response to the required green job skills shortages, vocational education and training should bear due responsibility. Should strengthen the training of teachers, improve green teachers. Teachers should have knowledge of green jobs, most of which should have work experience in the green, rather than non-green work experience researcher. Governments at all levels should take effective measures to strengthen vocational education teachers green construction, and constantly improve teacher training and training system. Teacher training and actively carry out vocational education training programs in research and development, initially formed to cover the Training of new teachers training, pre-service training for teachers and principals, improve service, advanced training, teacher education compliance and degree promotion at different levels and types of projects framework. In the national key construction base as a leader, as the main provincial base, school-based training is based on the formation of a flexible and open culture of vocational teachers training system. The introduction of relevant policy documents and constantly improves the management and training of vocational teachers training system. Extensive with teachers and principals to focus on teacher training activities and strives to improve the quality of teachers. Strengthen vocational education teachers' professional ethics, and constantly improve the social status and economic treatment of teachers. Promote the improvement of teachers' work in Post Employment, Employment improves quality, improve overall quality of teachers. New teachers in vocational college professional skills training, vocational education so that teaching staff of vocational education to meet the basic scale and quality improvement needs.

In Denmark, Germany, skills development main task is carried out by academic and vocational education programs, will take embedded apprenticeship learning in the formal education system 
initiatives. In Denmark, changes related to vocational education and training courses reflect the environment, environmental protection-oriented, reflecting the growth of green jobs. In Germany, the integration of environmental aspects in recent years, Germany has been strongly influenced by the education and training system. Environmental protection is included in both initial vocational training and university education training courses. Green Skills Training reasonable course is the key. Green jobs exist in many economic areas, such as: energy supply, recycling, agriculture, construction, transportation, and so on. They come through the implementation of energy efficient strategies to reduce energy, materials and water consumption, to achieve carbon-free economy, reduce greenhouse gas emissions, reduce or avoid all forms of waste and pollution, protection and rehabilitation of ecosystems and maintain biodiversity. Therefore, green curriculum is also present in many economic sectors, courses in different fields have their own characteristics. To arrange green course, grasp Liberal skills, highlighting the core technical skills. As a professional in different areas should be set up computer, English, interpersonal communication, environmental protection aspects of the curriculum; the curriculum in the transport sector to be involved in more energy-efficient vehicles, hybrid electric vehicles, electric vehicles and fuel cell vehicles, car sharing, etc.; in the course of the manufacturing sector to highlight pollution control, efficient use of energy and raw materials, cleaner production technology; in the construction industry in the field of curriculum to emphasize energy conservation lighting equipment, household appliances and office equipment, solar heating and cooling and solar panels, Reconstruction of buildings, green building, recycling materials management; courses in the field of agriculture involves soil protection, water conservation, organic natural production methods to reduce farm from the market and so on.

\section{Acknowledgements}

Asia-Pacific Economic Cooperation Organization "Vocational Education and Training System Green Skills' project (HRD 01 2014A-Systematic Development in TVE)

\section{REFERENCE:}

[1] United Nations Environment Programme, Green Jobs: Towards Decent Work in A Sustainable, Low-Carbon World [R].2008(9):1- 25.

[2] International Labour Organization, Skills for Green Jobs: A Global View[R].2011.

[3] International Labour Organization, Skill for Green Jobs: A Global View [R].2011.

[4] International Labour Organization, Green Jobs Becoming are Ality: Progress and Outlook 2012 [R].2011(3). 